\title{
Improvement in Structural and Magnetic Properties of Electrospun $\mathrm{Ni}_{1-\mathrm{x}} \mathrm{Cu}_{\mathrm{x}} \mathrm{Fe}_{2} \mathrm{O}_{4}$ Nanofibers
}

\author{
Weiwei Pan1*, Xinlei Zhang², Qin-Fang Liu², Jianbo Wang² \\ ${ }^{1}$ School of Physics and Electronic Science, Guizhou Normal College, Guiyang, China \\ ${ }^{2}$ Institute of Applied Magnetics, Key Laboratory of Magnetism and Magnetic Materials of Ministry of Education, Lanzhou \\ University, Lanzhou, China \\ Email: *panweiwei27@163.com
}

How to cite this paper: Pan, W.W., Zhang, X.L., Liu, Q.-F. and Wang, J.B. (2017) Improvement in Structural and Magnetic Properties of Electrospun $\mathrm{Ni}_{1-\mathrm{x}} \mathrm{Cu}_{\mathrm{x}} \mathrm{Fe}_{2} \mathrm{O}_{4}$ Nanofibers. Soft Nanoscience Letters, 7, 17-26.

https://doi.org/10.4236/snl.2017.72002

Received: September 19, 2017

Accepted: November 6, 2017

Published: November 9, 2017

Copyright $\odot 2017$ by authors and Scientific Research Publishing Inc. This work is licensed under the Creative Commons Attribution International License (CC BY 4.0). http://creativecommons.org/licenses/by/4.0/

\begin{abstract}
A series of $\mathrm{Ni}_{1-\mathrm{x}} \mathrm{Cu}_{\mathrm{x}} \mathrm{Fe}_{2} \mathrm{O}_{4}(0.0 \leq \mathrm{x} \leq 1.0)$ nanofibers have been synthesized employing electrospinning method at $650^{\circ} \mathrm{C}$. The effect of $\mathrm{Cu}$ substitution on structural, morphology and magnetic properties of $\mathrm{NiFe}_{2} \mathrm{O}_{4}$ nanofibers is reported. The XRD analysis showed the formation of single-phase cubic spinel $\mathrm{Ni}-\mathrm{Cu}$ ferrite and an increasing behavior of lattice constant. The surface morphology is characterized by SEM, it is investigated that nanofibers have uniform and continuous morphology. The VSM results showed $\mathrm{Cu}$ substitution played an important role in magnetic properties of $\mathrm{Ni}_{1-\mathrm{x}} \mathrm{Cu}_{\mathrm{x}} \mathrm{Fe}_{2} \mathrm{O}_{4}$. The saturation magnetization $\left(M_{\mathrm{s}}\right)$ decreases linearly with increasing $\mathrm{Cu}^{2+}$ content, while coercivity $\left(H_{\mathrm{c}}\right)$ has slowly decreased before $\mathrm{x} \leq 0.5$, and then sharply increased to 723.9 Oe for $x=1.0$. The magnetic properties of $\mathrm{Ni}_{1-\mathrm{x}} \mathrm{Cu}_{\mathrm{x}} \mathrm{Fe}_{2} \mathrm{O}_{4}$ can be explained in Neel's model, cation distribution and shape anisotropy.
\end{abstract}

\section{Keywords}

$\mathrm{NiCu}$ Ferrite, Electrospinning, Magnetic Properties, Nanostructures

\section{Introduction}

One-dimensional (1D) nanostructures of spinel ferrite have been a subject of intense research for their interesting chemical and physical properties which different from those of bulk materials [1]. Spinel ferrite with a general formulae $\mathrm{MFe}_{2} \mathrm{O}_{4}$ (where $\mathrm{M}=\mathrm{Co}, \mathrm{Ni}, \mathrm{Fe}, \mathrm{Mg}, \mathrm{Mn}, \mathrm{Zn}$, and $\mathrm{Cu}$ ) are widely used for many kinds of industrial applications such as optical, catalytic, sustainable hydrogen production application and electronic and magnetic devices [2] [3] [4]. Among, 
$\mathrm{NiFe}_{2} \mathrm{O}_{4}$ is a one of most investigated spinel ferrite because of their remarkable properties such as high electrical resistivity, high mechanical hardness, large permeability at high frequency and chemical stability. The structural and magnetic properties of $\mathrm{NiFe}_{2} \mathrm{O}_{4}$ are particularly affected at cation distribution and the type of substitution [5] [6]. Among many ion doping, Cu substitution $\mathrm{NiFe}_{2} \mathrm{O}_{4}$ have been the subject of extensive investigation because of the high frequency application as magnetic materials [7]. $\mathrm{NiFe}_{2} \mathrm{O}_{4}$ is a completely inverse spinel $\left.(\mathrm{Fe})[\mathrm{NiFe}] \mathrm{O}_{4}\right), \mathrm{Ni}^{2+}$ have a strong preference for octahedral site (B-site), while $\mathrm{CuFe}_{2} \mathrm{O}_{4}$ is a partial inverse spinel $\left(\mathrm{Cu}_{\mathrm{x}} \mathrm{Fe}_{1-\mathrm{x}}\right)\left[\mathrm{Cu}_{1-\mathrm{x}} \mathrm{Fe}_{1+\mathrm{x}}\right] \mathrm{O}_{4}, \mathrm{Cu}^{2+}$ have a preference for tetrahedral site (A-site) and B-site. The substitution of $\mathrm{Cu}$ in $\mathrm{NiFe}_{2} \mathrm{O}_{4}$ brings about a structural phase transition, makes them a suitable material for various technological applications due to the interesting magnetic and electrical properties [8] [9].

In earlier work, with increasing copper content the saturation magnetization of $\mathrm{Ni}_{1-\mathrm{x}} \mathrm{Cu}_{\mathrm{x}} \mathrm{Fe}_{2} \mathrm{O}_{4}$ microparticles prepared by double-sintering method decreases linearly, whereas coercivity decreases up to $\mathrm{x}=0.6$ and then increases [10]. The effect of $\mathrm{Cu}$ substitution on chemical states of surface ions and surface composition in $\mathrm{Ni}_{1-\mathrm{x}} \mathrm{Cu}_{\mathrm{x}} \mathrm{Fe}_{2} \mathrm{O}_{4}$ spherical nanoparticles prepared by sol-gel combustion method [11], and the effect of $\mathrm{Cu}^{2+}$ substitution on electromagnetic properties of $\mathrm{Ni}_{1-\mathrm{x}} \mathrm{Cu}_{\mathrm{x}} \mathrm{Fe}_{2} \mathrm{O}_{4}$ nanoparticles is well studied [12]. Similar structure and magnetic properties are obtained for $\mathrm{Ni}_{1-\mathrm{x}} \mathrm{Cu}_{\mathrm{x}} \mathrm{Fe}_{2} \mathrm{O}_{4}$ nanostructures prepared by citrate-gel auto combustion technique [13], microwave-induced combustion [14], co-precipitation method [15] [16], and ceramic method [17] [18]. Compared to commercial mechanical process, electrospinning represents a simple, effective and convenient method for generating 1D nanofibers [19]. One of the most important advantages of electrospinning is the ability to control the component of composites, morphology and diameter of nanofibers. Electrospun nanofibers have been applied in a broad range of applications owing to their large specific surface area, high aspect ration, and good dimensional stability [20].

In this paper, a series of $\mathrm{Ni}_{1-\mathrm{x}} \mathrm{Cu}_{\mathrm{x}} \mathrm{Fe}_{2} \mathrm{O}_{4}$ (where, $\mathrm{x}=0.0,0.3,0.5,0.7,1.0$ ) nanofibers have been prepared by electrospinning method. The effect of $\mathrm{Cu}$ substitution on structural, morphology and magnetic properties of $\mathrm{NiFe}_{2} \mathrm{O}_{4}$ nanofibers will be studied.

\section{Experimental}

\subsection{Preparation of $\mathrm{Ni}_{1-\mathrm{x}} \mathrm{Cu}_{\mathrm{x}} \mathrm{Fe}_{2} \mathrm{O}_{4}$ Nanofibers}

In this study, the raw materials including $\mathrm{Ni}\left(\mathrm{NO}_{3}\right)_{2} \cdot 6 \mathrm{HO}_{2}, \mathrm{Cu}\left(\mathrm{NO}_{3}\right)_{2} \cdot 3 \mathrm{HO}_{2}$, $\mathrm{Fe}\left(\mathrm{NO}_{3}\right)_{3} \cdot 9 \mathrm{HO}_{2}$ and PVP (polyvinylpyrrolidone, $\mathrm{Mw} \approx 1,300,000$ ) were of analytical grade and purchased from Tianjin Guangfu. DMF ( $N, N$-Dimethylformamide, $99.7 \%$ purity, Tianjin Guangfu, China) and ethanol (100\% purity) were used as solvents. In the solution preparation, $0.1 \mathrm{~g}$ of PVP was dissolved in mixture of ethanol and DMF with a weight ratio of 1:1, followed by magnetic stirring for $2 \mathrm{~h}$ to ensure the dissolution of PVP. Then $\mathrm{Ni}\left(\mathrm{NO}_{3}\right)_{2} \cdot 6 \mathrm{HO}_{2}$, 
$\mathrm{Cu}\left(\mathrm{NO}_{3}\right)_{2} \cdot 3 \mathrm{HO}_{2}, \mathrm{Fe}\left(\mathrm{NO}_{3}\right)_{3} \cdot 9 \mathrm{HO}_{2}$ with a molar ratio of $(1-\mathrm{x}): \mathrm{x}: 2$ were added into the mixture solution. After having been stirred for $2 \mathrm{~h}$, the homogeneous viscous solution was transferred into a plastic syringe in which a needle made of stainless steel was connected to a high-voltage equipment. The applied voltage was kept at $+15 \mathrm{kV}$ during the electrospinning process. The nanofibers were collected on a piece of aluminum foil about $15 \mathrm{~cm}$ below the tip of needle. All electrospinning processes were carried out at room temperature. The collected $\mathrm{Ni}_{1-\mathrm{x}} \mathrm{Cu}_{\mathrm{x}} \mathrm{Fe}_{2} \mathrm{O}_{4} / \mathrm{PVP}$ precursor nanofibers were dried at $80^{\circ} \mathrm{C}$ for $3 \mathrm{~h}$, and calcined at $650^{\circ} \mathrm{C}$ for $3 \mathrm{~h}$ in ambient atmosphere with a heating rate of $1^{\circ} \mathrm{C} / \mathrm{min}$.

\subsection{Characterization}

The calcined nanofibers were characterized by X-ray diffraction (XRD) pattern using $\mathrm{CuKa}$ radiation with $\lambda=0.15418 \mathrm{~nm}$ (PANalytical diffractometer). The scanning electron microscope (SEM, Hitachi S-4800) and transmission electron microscope (TEM, Tecnai ${ }^{\mathrm{TM}} \mathrm{G}^{2}$ F30, FEI) were employed to analyze morphology and microstructure of samples. Infrared spectra were obtained using Fourier transform infrared spectroscopy (FT-IR, Nicolet 6700) in the $400-4000 \mathrm{~cm}^{-1}$ range. The magnetic properties of nanofibers were measured at room temperature using vibrating sample magnetometer (VSM. Lakeshore 7403, USA) with a maximum applied field of $12 \mathrm{kOe}$.

\section{Results and Discussion}

\subsection{Structural Studies}

The effect of $\mathrm{Cu}$ substitution on structural and morphology of $\mathrm{NiFe}_{2} \mathrm{O}_{4}$ nanofibers was been studied by XRD, SEM and TEM. The XRD patterns of synthesized $\mathrm{Ni}_{1-\mathrm{X}} \mathrm{Cu}_{\mathrm{x}} \mathrm{Fe}_{2} \mathrm{O}_{4}$ nanofibers calcined at $650^{\circ} \mathrm{C}$ for $3 \mathrm{~h}$ are shown in Figure 1 . All of main diffraction peaks are indexed as the cubic spinel structure, no second phase can be detected. The position of peaks is slightly shifted to lower angle with increasing $\mathrm{Cu}^{2+}$ content. The diffraction peaks of samples for $\mathrm{x} \leq 0.5$ correspond to

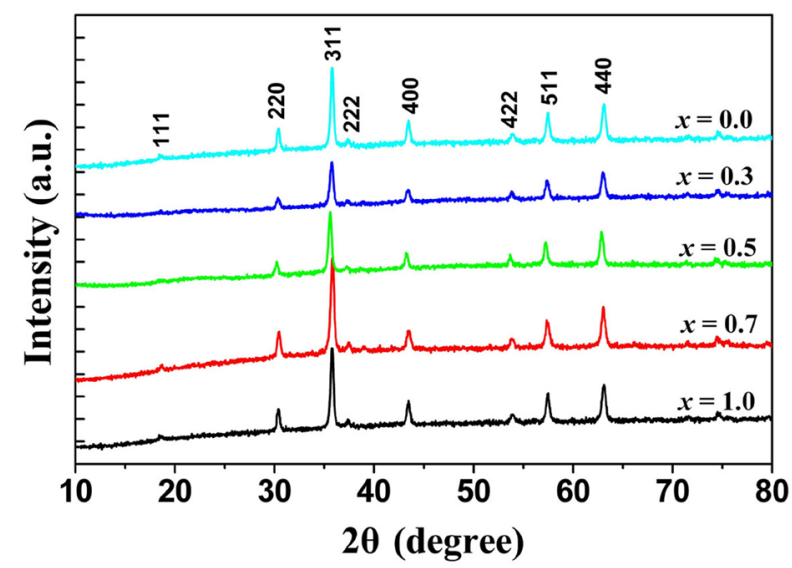

Figure 1. X-ray diffraction patterns of $\mathrm{Ni}_{1-\mathrm{x}} \mathrm{Cu}_{\mathrm{x}} \mathrm{Fe}_{2} \mathrm{O}_{4}(0.0 \leq \mathrm{x}$ $\leq 1.0$ ) nanofibers calcined at $650^{\circ} \mathrm{C}$ for $3 \mathrm{~h}$. 
$\mathrm{NiFe}_{2} \mathrm{O}_{4}$, while the diffraction peaks of samples for $\mathrm{x} \geq 0.7$ correspond to $\mathrm{CuFe}_{2} \mathrm{O}_{4}$. The lattice constant $a$ is calculated by using equation:

$$
a=d\left(h^{2}+k^{2}+l^{2}\right),
$$

where $d$ is the interplanar distance and $h, k, l$ is the Miller indices of plane [21]. The average crystallite size $D$ is calculated using Debye-Scherrer's formula with respect to peak plane (311). The values of $a$ and $D$ are extracted and listed in Table 1. From Table 1 it can been seen that lattice constant increases with increasing $\mathrm{Cu}^{2+}$ content. The increased a may be explained on the bigger ionic radii of $\mathrm{Cu}^{2+}$ ions $(0.72 \AA)$ than $\mathrm{Ni}^{2+}$ ions $(0.69 \AA)$, indicating $\mathrm{Cu}^{2+}$ ions can be effectively built into $\mathrm{NiFe}_{2} \mathrm{O}_{4}$ lattice. The average crystallite size increases initially with $\mathrm{Cu}^{2+}$ contents, the maximum $D$ occurs at $\mathrm{x}=0.5(D=24.1 \mathrm{~nm})$, and then decreases. The variation of $a$ and $D$ with $\mathrm{Cu}^{2+}$ content mainly attributed to the $\mathrm{Cu}^{2+}$ ions insert into the cubic spinel structure, the similar trends were observed in $\mathrm{Ni}_{1-\mathrm{x}} \mathrm{Cu}_{\mathrm{x}} \mathrm{Fe}_{2} \mathrm{O}_{4}$ nanoparticles prepared by sol-gel combustion method [11].

\subsection{Morphological Studies}

The morphology of $\mathrm{Ni}_{1-\mathrm{x}} \mathrm{Cu}_{\mathrm{x}} \mathrm{Fe}_{2} \mathrm{O}_{4}$ nanofibers were investigated by SEM and TEM. Figure 2 shows the SEM images of $\mathrm{Ni}_{1-\mathrm{x}} \mathrm{Cu}_{\mathrm{x}} \mathrm{Fe}_{2} \mathrm{O}_{4}$ nanofibers calcined at $650^{\circ} \mathrm{C}$. It can be seen that all samples remained as continuous and randomly oriented morphology, the diameter of nanofibers is about $50-60 \mathrm{~nm}$. The surface of nanofibers is smooth when $\mathrm{x}$ less than 0.3 , rough surface were observed after $\mathrm{x}$ increasing to 0.5 and 0.7 , the surface of $\mathrm{CuFe}_{2} \mathrm{O}_{4}$ nanofibers $(x=1.0)$ consists of small open porosity. A similar result was also observed in $\mathrm{Ni}_{0.5-\mathrm{x}} \mathrm{Cu}_{\mathrm{x}} \mathrm{Zn}_{0.5} \mathrm{Fe}_{2} \mathrm{O}_{4}$ nanofibers with $\mathrm{x}=0.0-0.5$ prepared by electrospinning [22]. The $\mathrm{Cu}^{2+}$ content has some influences on morphology of $\mathrm{Ni}_{1-\mathrm{x}} \mathrm{Cu}_{\mathrm{x}} \mathrm{Fe}_{2} \mathrm{O}_{4}$ nanofibers. Figure 3 shows the typical TEM (a-b) and HRTEM (c-d) images of $\mathrm{Ni}_{0.5} \mathrm{Cu}_{0.5} \mathrm{Fe}_{2} \mathrm{O}_{4}$ nanofibers, respectively. From Figure 3(a) and Figure 3(b), it can be seen that these nanofibers exhibited a fibrous, continuous and good dispersity morphology, and a nanofiber is composed of randomly aligned nanoparticles. This is well consistent with that observed from SEM (Figure 2). In HRTEM image of $\mathrm{Ni}_{0.5} \mathrm{Cu}_{0.5} \mathrm{Fe}_{2} \mathrm{O}_{4}$ nanofibers (Figure $3(\mathrm{c})$ ), the crystalline phase has well-resolved lattice fringes. The value of distance between the adjacent

Table 1. Parameters extracted from XRD and VSM for $\mathrm{Ni}_{1-\mathrm{x}} \mathrm{Cu}_{\mathrm{x}} \mathrm{Fe}_{2} \mathrm{O}_{4}$ nanofibers system: lattice contant $(a)$, average crystallite size $(D)$, saturation magnetization $\left(M_{\mathrm{s}}\right)$, remanent magnetization $\left(M_{\mathrm{r}}\right)$ and coercivity $\left(H_{\mathrm{c}}\right)$.

\begin{tabular}{cccccc}
\hline $\begin{array}{c}\text { Sample } \\
\mathrm{Ni}_{1-\mathrm{x}} \mathrm{Cu}_{\mathrm{x}} \mathrm{Fe}_{2} \mathrm{O}_{4}\end{array}$ & $\begin{array}{c}\text { Lattice } \\
\text { constant } a(\AA)\end{array}$ & $\begin{array}{c}\text { Average } \\
\text { Crystallite size } D(\mathrm{~nm})\end{array}$ & $\begin{array}{c}M_{\mathrm{s}} \\
(\mathrm{emu} / \mathrm{g})\end{array}$ & $\begin{array}{c}M_{\mathrm{r}} \\
(\mathrm{emu} / \mathrm{g})\end{array}$ & $\begin{array}{c}H_{\mathrm{c}} \\
\mathrm{Oe}\end{array}$ \\
\hline$x=0.0$ & 8.3187 & 20.9 & 47.0 & 14.9 & 172.2 \\
$X=0.3$ & 8.3223 & 23.4 & 45.1 & 14.3 & 169.0 \\
$X=0.5$ & 8.3344 & 24.1 & 40.3 & 13.0 & 165.3 \\
$X=0.7$ & 8.3525 & 20.4 & 34.8 & 11.8 & 189.4 \\
$X=1.0$ & 8.3856 & 19.7 & 31.8 & 14.9 & 723.9 \\
\hline
\end{tabular}




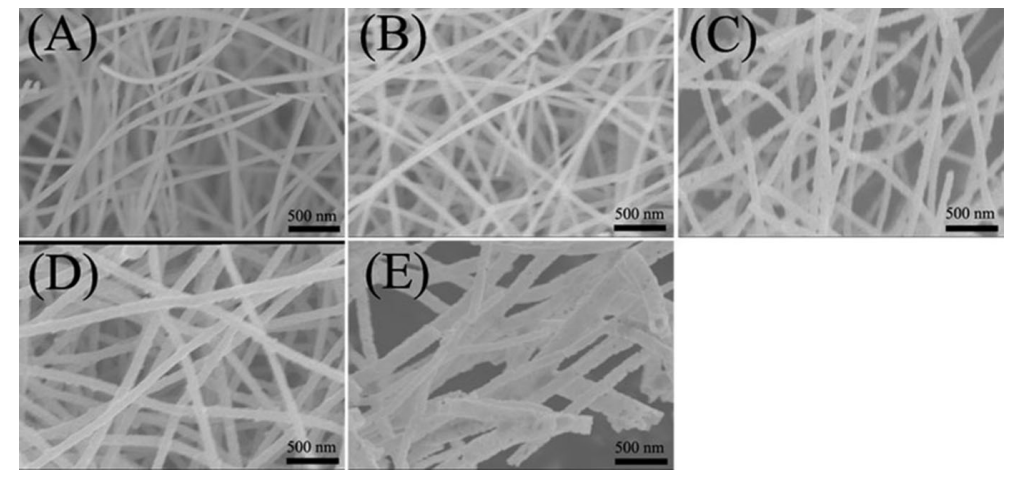

Figure 2. SEM images of $\mathrm{Ni}_{1-\mathrm{x}} \mathrm{Cu}_{\mathrm{x}} \mathrm{Fe}_{2} \mathrm{O}_{4}$ nanofibers with different $\mathrm{Cu}^{2+}$ content: (A) $\mathrm{x}=0.0$; (B) $\mathrm{x}=0.3$; (C) $\mathrm{x}=0.5$; (D) $\mathrm{x}=0.7$ and (E) $\mathrm{x}=1.0$.

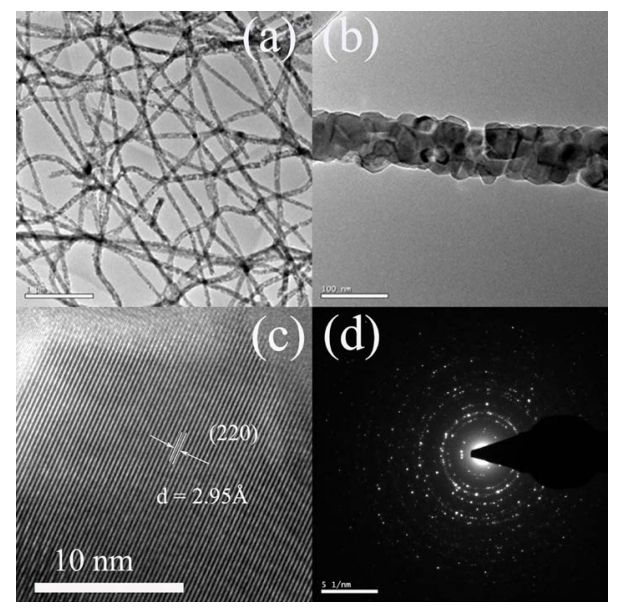

Figure 3. (a) (b) TEM images; (c) HRTEM image; and (d) SAED pattern of $\mathrm{Ni}_{0.5} \mathrm{Cu}_{0.5} \mathrm{Fe}_{2} \mathrm{O}_{4}$ nanofibers.

lattice is $2.95 \AA$, which is in agreement with the XRD patterns. As shown in Figure $3(\mathrm{~d})$, selected area electron diffraction (SEAD) of $\mathrm{Ni}_{0.5} \mathrm{Cu}_{0.5} \mathrm{Fe}_{2} \mathrm{O}_{4}$ nanofibers consists of multiple intense rings, indicating that the sample has a polycrystalline nature.

\subsection{FT-IR Studies}

The ideal spinel structure consists of two sub-lattices, namely tetrahedral sites (A) and octahedral sites (B). Different charge combinations of metal cations are distributed in A and B sites. Therefore, the magnetic properties of spinel ferrite are to a large extent determined by the class of metal ions and cation distribution among the $\mathrm{A}$ and $\mathrm{B}$ sites. In $\mathrm{Ni}_{1-\mathrm{x}} \mathrm{Cu}_{\mathrm{x}} \mathrm{Fe}_{2} \mathrm{O}_{4}$ nanofibers, the replacement of $\mathrm{Ni}^{2+}$ ions with $\mathrm{Cu}^{2+}$ ions at $\mathrm{B}$ sites will influence the magnetic properties of samples. FT-IR spectra is usually assigned to the vibration of ions in crystal lattice, which can been used to confirmed the positions of $\mathrm{Ni}^{2+}, \mathrm{Cu}^{2+}$, and $\mathrm{Fe}^{3+}$ ions in spinel structure. The vibrating sample magnetometer is used to measure the magnetic properties of samples.

Figure 4 shows the typical FT-IR spectra of $\mathrm{Ni}_{1-\mathrm{x}} \mathrm{Cu}_{\mathrm{x}} \mathrm{Fe}_{2} \mathrm{O}_{4}$ nanofibers recorded 


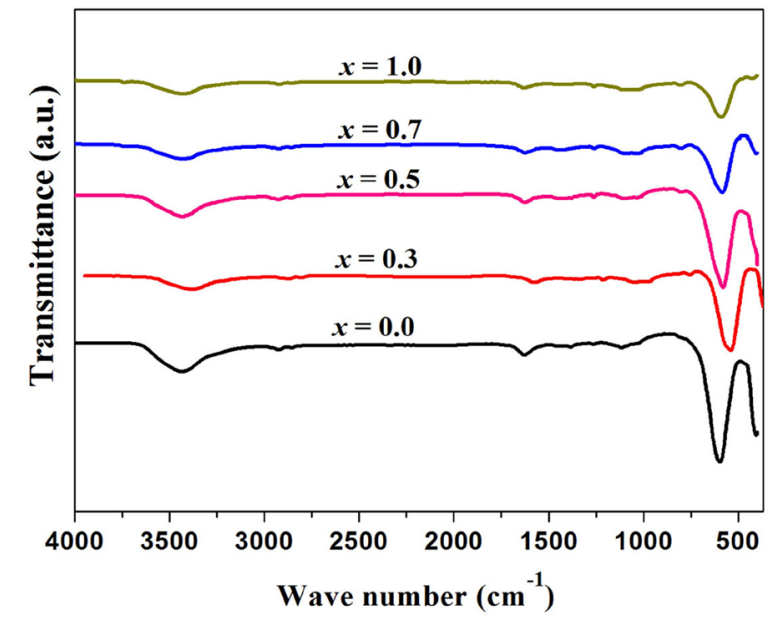

Figure 4. FT-IR spectra of $\mathrm{Ni}_{1-\mathrm{x}} \mathrm{Cu}_{\mathrm{x}} \mathrm{Fe}_{2} \mathrm{O}_{4}(0.0 \leq \mathrm{x} \leq 1.0)$ nanofibers.

between 4000 and $400 \mathrm{~cm}^{-1}$. In the range of $1000-400 \mathrm{~cm}^{-1}$, two main absorption bands of ferrite are appear. The absorption band $v_{1}=580 \mathrm{~cm}^{-1}$ is assigned to the stretching vibration of tetrahedral complexes $\left(\mathrm{Fe}^{3+}-\mathrm{O}^{2-}\right)$, and the absorption band $v_{2}=400 \mathrm{~cm}^{-1}$ is attributed to the octahedral complexes $\left(\mathrm{Fe}^{3+}-\mathrm{O}^{2-}\right)$. The peak intensity of $v_{1}$ decreases with increasing $\mathrm{Cu}^{2+}$ contents, while the position band is shifted to lower frequencies. Synchronously, the intensity and position of $v_{2}$ changed slightly with $x$. Similar results are observed in $\mathrm{Ni}_{1-\mathrm{x}} \mathrm{Cu}_{\mathrm{x}} \mathrm{Fe}_{2} \mathrm{O}_{4}$ nanoparticles prepared by sol-gel combustion method [11] [23]. The difference in band position of $v_{1}$ and $v_{2}$ can be related to the difference in $\mathrm{Fe}^{3+}-\mathrm{O}^{2}$ bond lengths at $\mathrm{A}$ sites and $\mathrm{B}$ sites. It was found that the $\mathrm{Fe}-\mathrm{O}$ distance at A sites $(1.89 \AA)$ is smaller than that of the $\mathrm{B}$ sites $(2.03 \AA)$ [24] [25]. When $\mathrm{Ni}^{2+}$ ions is replaced by $\mathrm{Cu}^{2+}$ ions, due to charge imbalance some $\mathrm{Fe}^{3+}$ ions shift from $\mathrm{A}$ sites to $\mathrm{B}$ sites, making the $\mathrm{Fe}^{3+}-\mathrm{O}^{2}$ stretching vibration in greater. So the decrease in peak intensity of $v_{1}$ with increasing $\mathrm{Cu}^{2+}$ content is mainly attributed to the change in $\mathrm{Fe}^{3+}-\mathrm{O}^{2}$ bands.

\subsection{Magnetic Studies}

The magnetic structure of spinel ferrite is ferrimagnetic, the magnetic moments of A and B sites are coupled antiparallel to each other. There are twice as many B sites filled, so there is a net magnetic moment equal to the difference between the two sites. The magnetization behavior of spinel ferrite can be understood in Neel's model. In $\mathrm{Ni}_{1-\mathrm{x}} \mathrm{Cu}_{\mathrm{x}} \mathrm{Fe}_{2} \mathrm{O}_{4}$ nanofibers, the composition and cation distribution among the $\mathrm{A}$ and $\mathrm{B}$ sites will influence the magnetic properties of samples. Figure 5 shows magnetic hysteresis loops for $\mathrm{Ni}_{1-\mathrm{x}} \mathrm{Cu}_{\mathrm{x}} \mathrm{Fe}_{2} \mathrm{O}_{4}$ nanofibers measured at room temperature, the values of saturation magnetization $\left(M_{s}\right)$, remanent magnetization $\left(M_{\mathrm{r}}\right)$ and coercivity $\left(H_{\mathrm{c}}\right)$ are calculated from loops and given in Table 1. From the figure it is noticed that the value of $M_{\mathrm{s}}$ decreases linearly with increasing $\mathrm{Cu}^{2+}$ content, while $M_{\mathrm{r}}$ gradually decreases up to $\mathrm{x}=0.7$, then increases small for $\mathrm{x}=1.0$. The $H_{c}$ decreases up to $\mathrm{x}=0.5$ with $x$, after it sharply 


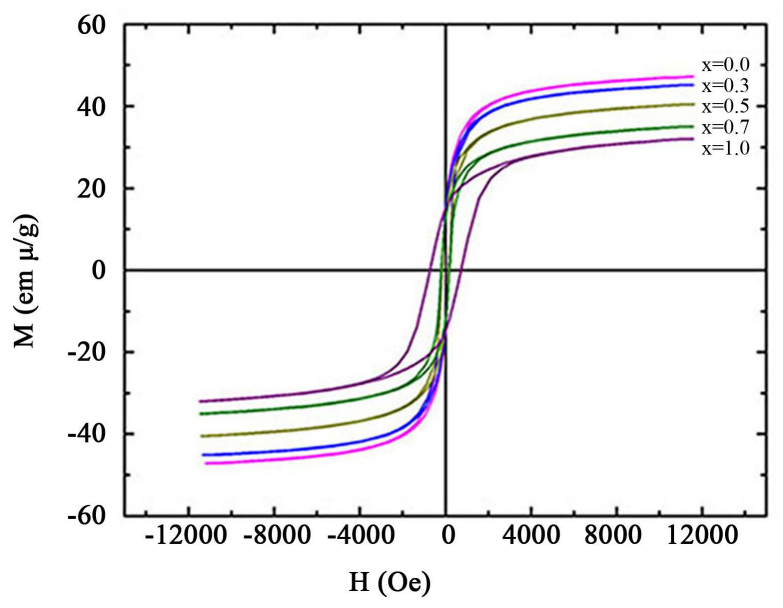

Figure 5. Magnetic hysteresis loops for $\mathrm{Ni}_{1-\mathrm{x}} \mathrm{Cu}_{\mathrm{x}} \mathrm{Fe}_{2} \mathrm{O}_{4}(0.0 \leq \mathrm{x}$ $\leq 1.0$ ) nanofibers at room temperature.

increase to 723.9 Oe for $\mathrm{x}=1.0$.

According to Neel's model, the magnetic moment per formula is expressed as:

$$
\mu_{B}=M_{B}(x)-M_{A}(x),
$$

where $M_{\mathrm{B}}$ and $M_{\mathrm{A}}$ are magnetic moments of $\mathrm{B}$ and $\mathrm{A}$ sites in $\mu_{B}$. It is well know $\mathrm{NiFe}_{2} \mathrm{O}_{4}$ is an inverse spinel structure, all $\mathrm{Ni}^{2+}$ ion and a $\mathrm{Fe}^{3+}$ ion occupy $\mathrm{B}$ sites, other $\mathrm{Fe}^{3+}$ ion occupy A sites. $\mathrm{CuFe}_{2} \mathrm{O}_{4}$ is a partial inverse spinel structure with $85 \% \mathrm{Cu}^{2+}$ at $\mathrm{B}$ sites, other $15 \%$ at $\mathrm{A}$ sies [25]. The magnetic moment of $\mathrm{Cu}^{2+}$ ions $\left(1.0 \mu_{B}\right)$ is smaller than $\mathrm{Ni}^{2+}$ ions $\left(2.3 \mu_{B}\right)$ [23]. The $\mathrm{Cu}^{2+}$ ions are substituted instead of $\mathrm{Ni}^{2+}$ ions result in a decrease in net magnetic moment of samples. A part of $\mathrm{Cu}^{2+}$ ions occupy $\mathrm{A}$ sites leading to a migration of $\mathrm{Fe}^{3+}$ ions from $\mathrm{A}$ sites to $\mathrm{B}$ sites. With increasing $\mathrm{Cu}^{2+}$ content, the super-exchange interaction between $\mathrm{A}$ and $B$ sites decreases. Therefore, the decrease trend in saturation magnetization and remanent magnetization is agreed with that of an expected decrease in $\mathrm{Ni}_{1-\mathrm{x}} \mathrm{Cu}_{\mathrm{x}} \mathrm{Fe}_{2} \mathrm{O}_{4}$ nanofibers.

The variation of $H_{c}$ with $\mathrm{Cu}^{2+}$ contents can be understood on basis of domain structure, anisotropy and critical diameter [26]. The initial decrease trend of $H_{c}$ $(x \leq 0.5)$ is due to the increase in crystallite size, which is observed in XRD results. This may be attributed to the magnetization mechanism which is a domain rotation process. The $H_{c}$ value of 723.9 Oe obtained for $\mathrm{CuFe}_{2} \mathrm{O}_{4}$ nanofibers in present work is higher than the value of $93.7 \mathrm{Oe}$ and $151.0 \mathrm{Oe}$ of $\mathrm{CuFe}_{2} \mathrm{O}_{4}$ nanoparticles prepared by double-sintering method and coprecipitation method, respectively [10] [23]. This values is also higher than $H_{c}=625.0$ Oe for $\mathrm{CuFe}_{2} \mathrm{O}_{4}$ nanofibers prepared by electrospinning method [27]. The high value of $H_{c}$ in this paper may be attributed to the magnetocrystalline and shape anisotropy. The magnetocrystalline anisotropy of $\mathrm{CuFe}_{2} \mathrm{O}_{4}$ nanofibers is about $0.6 \times 10^{5} \mathrm{erg}$ $\mathrm{cm}^{-3}$, while shape anisotropy is calculated to be $k_{\mathrm{s}}=1.7 \times 10^{5} \mathrm{erg} \mathrm{cm}^{-3}$ using the measured $M_{\mathrm{s}}\left(31.8 \mathrm{emu} \mathrm{g}^{-1}\right)$ [28], which is higher than magnetocrystalline anisotropy. Therefore, the high $H_{c}$ of $\mathrm{CuFe}_{2} \mathrm{O}_{4}$ nanofibers mainly come from shape 
anisotropy if we neglect the dipolar interactions between nanofibers. In Refer. 15, the breakdown of fibers morphology result to lower $H_{\mathrm{c}}$ than this work, while in this paper $\mathrm{CuFe}_{2} \mathrm{O}_{4}$ sample retain favorable nanofibers morphology.

\section{Conclusion}

The class of metal ions and cation distribution among $\mathrm{A}$ and $\mathrm{B}$ sites will affect the magnetic properties of spinel ferrite. Nanofibers morphology produced a difference characteristic compare with nanoparticles ones. In this paper, $\mathrm{Ni}_{1-\mathrm{x}} \mathrm{Cu}_{\mathrm{x}} \mathrm{Fe}_{2} \mathrm{O}_{4}$ nanofibers $(0.0 \leq \mathrm{x} \leq 1.0)$ were prepared by electrospinning method, the effect of copper substitution on structure, morphology and magnetic properties of $\mathrm{NiFe}_{2} \mathrm{O}_{4}$ nanofibers is studied. Increasing the $\mathrm{Cu}^{2+}$ ion causes an increase in lattice constant due to the larger ionic radii of $\mathrm{Cu}$ ion. All samples remain as continuous fibers morphology, while surface of nanofibers with $\mathrm{x} \leq$ 0.3 is smooth, it becomes rough and porous for $\mathrm{x}=0.5-0.7$ and $\mathrm{x}=1.0$. FT-IR spectra is used to confirmed the positions of $\mathrm{Ni}^{2+}, \mathrm{Cu}^{2+}$, and $\mathrm{Fe}^{3+}$ ions in spinel structure. Magnetic properties of $\mathrm{Ni}_{1-\mathrm{x}} \mathrm{Cu}_{\mathrm{x}} \mathrm{Fe}_{2} \mathrm{O}_{4}$ nanofibers are studied using vibrating sample magnetometer at room temperature. With increasing $\mathrm{Cu}^{2+}$ content, the saturation magnetization $\left(M_{\mathrm{s}}\right)$ was observed to decrease, while the coercivity $\left(H_{c}\right)$ decreased up to $\mathrm{x}=0.5$ and then sharply increased to 723.9 Oe for $\mathrm{x}=$ 1.0. The high coercivity of $\mathrm{CuFe}_{2} \mathrm{O}_{4}$ nanofibers compare with nanoparticles samples mainly comes from shape anisotropy of nanofibers. These observations provided by this work gave a fundamental understanding of nanofibers morphology prepared by electrospinning method.

\section{Acknowledgements}

This paper was supported by the Science and Technology Fund of Guizhou (J[2014]2143), the Scientific Research Fund of Guizhou Normal College (13BS014) and the Grant of Guizhou Normal College (107003001455).

\section{References}

[1] Sugimoto, M. (1999) The Past, Present, and Future of Ferrites. Journal of the American Ceramic Society, 82, 269-280. https://doi.org/10.1111/j.1551-2916.1999.tb20058.x

[2] Manikandan, A., Sridhar, R., Antony, S.A. and Ramakrishna S. (2014) A Simple Aloe Vera Plant-Extracted Microwave and Conventional Combustion Synthesis: Morphological, Optical, Magnetic and Catalytic Properties of $\mathrm{CoFe}_{2} \mathrm{O}_{4}$ Nanostructures. Journal of Molecular Structure, 1076, 188-200. https://doi.org/10.1016/j.molstruc.2014.07.054

[3] Valan, M.F., Manikandan, A. and Arul Antony, S. (2015) A Novel Synthesis and Characterization Studies of Magnetic $\mathrm{Co}_{3} \mathrm{O}_{4}$ Nanoparticles. Journal of Nanoscience and Nanotechnology, 15, 4580-4586. https://doi.org/10.1166/jnn.2015.9776

[4] Mathubala, G., Manikandan, A., Arul Antony, S. and Ramar, P. (2016) Photocalalytic Degradation of Methylene Blue Dye and Magneto-Optical Studies of Magnetically Recyclable Spinel $\mathrm{Ni}_{\mathrm{x}} \mathrm{Mn}_{1-\mathrm{x}} \mathrm{Fe}_{2} \mathrm{O}_{4}(\mathrm{x}=0.0$ - 1.0) Nanoparticles. Journal of Molecular Structure, 1113, 79-87. https://doi.org/10.1016/j.molstruc.2016.02.032 
[5] Gupta, N., Jain, P., Rana, R. and Shrivastava, S. (2017) Current Development in Synthesis and Characterization of Nickel Ferrite Nanoparticle. Materialstoday: Proceeding, 4, 342-349. https://doi.org/10.1016/j.matpr.2017.01.031

[6] Horvath, M.P. (2000) Microwave Applications of Soft Ferrites. Journal of Magnetism and Magnetic Material, 215-216, 171-183.

https://doi.org/10.1016/S0304-8853(00)00106-2

[7] Zaki, H.M. (2012) Structure, Analysis and Some Magnetic Properties for Low Temperature Fired Ni-Cu Ferrite. Physics B Condensed Matter, 407. 2025-2031. https://doi.org/10.1016/j.physb.2012.01.134

[8] Rezlescu, N. and Rezlascu, E. (1974) Abnormal Dielectric Behaviour of Copper Containing Ferrites. Solid State Communications, 14, 69-72.

https://doi.org/10.1016/0038-1098(74)90234-8

[9] Dimri, M.C., Verma, A., Kashyap, S.C., Dube, D.C. and Thakur, O.P. (2006) Structural, Dielectric and Magnetic Properties of NiCuZn Ferrite Grown by Citrate Precursor Method. Materials Science and Engineering. B, 133, 42-48. https://doi.org/10.1016/j.mseb.2006.04.043

[10] Anjum, S., Rashid, A., Bashir, F., Pervaiz, M. and Zia, R. (2015) Effect of Cu Doped Nickel Ferrites on Structural, Magnetic and Dielectric Properties. Materialstoday: Proceeding, 2, 5559-5567. https://doi.org/10.1016/j.matpr.2015.11.086

[11] Tan, X.Y., Li, G.Y., Zhao, Y. and Hu, C.W. (2009) The Effect of Cu Content on the Structure of $\mathrm{Ni}_{1-\mathrm{x}} \mathrm{Cu}_{\mathrm{x}} \mathrm{Fe}_{2} \mathrm{O}_{4}$ Spinels. Materials Research Bulletin, 44, 2160-2168. https://doi.org/10.1016/j.materresbull.2009.08.018

[12] Azadmanjiri, J., Salehani, H.K., Barati, M.R. and Farzan, F. (2007) Preparation and Electromagnetic Properties of $\mathrm{Ni}_{1-\mathrm{x}} \mathrm{Cu}_{\mathrm{x}} \mathrm{Fe}_{2} \mathrm{O}_{4}$ Nanoparticle Ferrites by Sol-Gel Auto-Combustion Method. Materials Letters, 61, 84-87. https://doi.org/10.1016/j.matlet.2006.04.011

[13] Sridhar, R., Ravinder, D. and Vijaya Kumar, K. (2015) Temperature-Dependence Thermoelectric Power Studies of Mixed Ni-Cu Nano Ferrites. Journal of Alloys and Compounds, 645, 436-442. https://doi.org/10.1016/j.jallcom.2015.05.041

[14] Elshahawy, A.M., Mahmoud, M.H., Makhlouf, S.A. and Hamdeh, H.H. (2015) Role of $\mathrm{Cu}^{2+}$ Substitution on the Structural and Magnetic Properties of Ni-Ferrite Nanoparticles Synthesized by the Microwave-Combustion Method. Ceramics International, 41, 11264-11271. https://doi.org/10.1016/j.ceramint.2015.05.079

[15] Balavijayalakshmi, J., Suriyanarayanan, N. and Jayaprakash, R. (2015) Role of Copper on Structural, Magnetic and Dielectric Properties of Nickel Ferrite Nano Particles. Journal of Magnetism and Magnetic Material, 385, 302-307. https://doi.org/10.1016/j.jmmm.2015.03.036

[16] Doh, S.G., Kim, E.B., Lee, B.H. and Oh, J.H. (2004) Characteristics and Synthesis of $\mathrm{Cu}-\mathrm{Ni}$ Ferrite Nanopowders by Coprecipitation Method with Ultrasound Irradiation. Journal of Magnetism and Magnetic Material, 272-276, 2238-2240. https://doi.org/10.1016/j.jmmm.2003.12.926

[17] Roumaih, K. (2008) The Transport Properties of the Mixed Ni-Cu Ferrite. Journal of Alloys and Compounds, 465, 291-295. https://doi.org/10.1016/j.jallcom.2007.10.073

[18] Msomi, J. and Moyo, T. (2009) Effect of Domain Transformation on the Magnetic Properties of $\mathrm{Cu}_{\mathrm{x}} \mathrm{Ni}_{1-\mathrm{x}} \mathrm{Fe}_{2} \mathrm{O}_{4}$ Ferrites. Journal of Magnetism and Magnetic Material, 321, 1246-1250. https://doi.org/10.1016/j.jmmm.2008.11.003

[19] Greiner, A. and Wendorff, J.H. (2007) Electrospinning: A Fascinating Method for 
the Preparation of Untrathin Fibers. Angewandte Chemie International Edition, 46, 5670-5703. https://doi.org/10.1002/anie.200604646

[20] Lu, X.F., Wang, C. and Wei, Y. (2009) One-Dimensional Composite Nanomaterials: Synthesis by Electrospinning and Their Applications. Small, 21, 2349-2370. https://doi.org/10.1002/smll.200900445

[21] Safa, O.K. and Peter, C. (2006) Springer Handbook of Electronic and Photonic Materials. Springer-Verlag, New York, 349.

[22] Xiang, J., Shen, X.Q., Song, F.Z. and Liu, M.Q. (2010) Oen-Dimensional NiCuZn Ferrite Nanostructures: Fabrication, Structure, and Magnetic Properties. Journal of Solid State Chemistry, 183, 1239-1244. https://doi.org/10.1016/j.jssc.2010.03.041

[23] Gabal, M.A., Al Angari, Y.M. and Kadi, M.W. (2011) Structural and Magnetic Properties of Nanocrystalline $\mathrm{Ni}_{1-\mathrm{x}} \mathrm{Cu}_{\mathrm{x}} \mathrm{Fe}_{2} \mathrm{O}_{4}$ Prepared through Oxalates Precursors. Polyhedron, 30, 1185-1190. https://doi.org/10.1016/j.poly.2011.01.032

[24] Umare, S.S., Ningthoujam, R.S., Sharma, S.J., Shrivastrava, S., Kurian, S. and Gajbhiye, N.S. (2008) Mossbauer and Magnetic Studies on Nanocrystalline $\mathrm{NiFe}_{2} \mathrm{O}_{4}$ Particles Prepared by Ethylene Glycol Route. Hyperfine Interactions, 184, 235-243. https://doi.org/10.1007/s10751-008-9796-4

[25] Rais, A., Taibi, K., Addou, A., Zanoun, A. and Al-Douri, Y. (2014) Copper Substitution Effect on the Structural Properties of Nickel Ferrites. Ceramics International, 40, 14413-14419. https://doi.org/10.1016/j.ceramint.2014.06.037

[26] Farghali, A.A., Khedr, M.H. and Abdel Khalek, A.A. (2007) Catalytic Decomposition of Carbondioxide over Freshly Reduced Activated $\mathrm{CuFe}_{2} \mathrm{O}_{4}$ Nanocrystal. Journal of Materials Processing Technology, 181, 81-87. https://doi.org/10.1016/j.jmatprotec.2006.03.053

[27] Ponhan, W. and Maensiri, S. (2009) Fabrication and Magnetic Properties of Electrospin Copper Ferrite $\left(\mathrm{CuFe}_{2} \mathrm{O}_{4}\right)$ Nanofibers. Solid State Sciences, 11, 479-484. https://doi.org/10.1016/j.solidstatesciences.2008.06.019

[28] Buschow, K.H.J. (1995) Handbool of Magnetic Materials. Vol. 8, North-Holland, Amsterdam, 212. 